\title{
Reduction in Snap Bean Emergence by Seed Treatment with Dried Canola Residue
}

\author{
V.L. Smith ${ }^{1}$ \\ Department of Plant Pathology and Ecology, Connecticut Agricultural \\ Experiment Station, New Haven, CT 06504
}

Additional index words. damping-off, Brassica napus, Phaseolus vulgaris, soil fumigation

\begin{abstract}
Emergence of snap beans (Phaseolus vulgaris L.) in field soil in 1995 to 1997 was reduced by the addition of dried, ground canola [Brassica napus L. ssp. oleifera (Metzg.) Sinsk. f. biennis] leaves and petioles to the furrow at planting. Soil amendment with the tissue increased the number of nodules on bean roots in all years. In plots with reduced stand, leaf area was increased and yield on a per-plant basis was larger than in plots with a better stand. Total yield was increased in plots with fewer plants only in 1995 . Frequency of isolation of fungi that cause damping-off was not affected by the addition of canola at planting. When used as a seed treatment and incorporated at planting, canola residues were detrimental to emergence of snap bean.
\end{abstract}

Interest in the use of crucifers (Brassica sp.) as soil amendments to control soilborne plant pathogens has increased in recent years. Crucifers (and other genera) produce sulfurcontaining compounds called glucosinolates. Although high levels of endogenous glucosinolates render the plants unsuitable for use as animal feed or for human consumption (Auld et al., 1992), they make the plants more useful as green manure crops or soil amendments. Enzymatic hydrolysis of glucosinolates yields organic cyanides, isothiocyanates, oxazolidinethiones, and ionic thiocyanate (Brown and Morra, 1995; Gamliel and Stapleton, 1993; Sang et al., 1984). One of these hydrolysates, allyl isothiocyanate, is as toxic to Aphanomyces euteiches Drechs. as is methyl isothiocyanate, the active ingredient in a commercially produced soil fumigant (Lewis and Papavizas, 1971). Brown and Morra (1995) found that canola cultivars bred for other than food-quality oil contain high levels of glucosinolates. The cultivar used in the present study, 'Humus', was bred specifically to contain high levels of glucosinolates; it cannot be used for animal feed or food-quality oil (Auld et al., 1992). Use of crucifers as soil amendments or green manures may be a more environmentally friendly way to achieve a reduction in the numbers or viability of soilborne pathogens, than is use of commercial soil fumigants.

Preemergence and postemergence damp-

Received for publication 22 Mar. 1999. Accepted for publication 7 July 1999. A paper of the Journal Series of the Connecticut Agricultural Experiment Station. Mention of trade or company names does not imply endorsement by Connecticut Agricultural Experiment Station, or criticism of similar products not mentioned. The cost of publishing this paper was defrayed in part by the payment of page charges. Under postal regulations, this paper therefore must be hereby marked advertisement solely to indicate this fact.

${ }^{1}$ Assistant Scientist. E-mail address:

Victoria.Smith@po.state.ct.us ing-off, caused by several soilborne fungi, including Fusarium sp., Rhizoctonia solani Kühn, and Pythium sp., are major factors in poor stand establishment in garden and commercial plantings of snap beans (Hall, 1991). In previous studies, I achieved a reduction in damping-off of snap bean by application of a bran-prill formulation of the biological control fungus Gliocladium virens J.H. Miller, J.E. Giddens, and A.A. Foster (Smith, 1996). Although registration of biological control agents for soilborne plant pathogens has increased, the cost of using biological control agents remains high and may be prohibitive for the small farmer or for the home vegetable gardener. An easily grown crucifer, such as canola, might therefore be useful as a means of controlling damping-off.

Brassica tissues also reduce population levels of various soilborne fungi (Kirkegaard et al., 1996; Lewis and Papavizas, 1971; Muehlihen et al., 1990; Papavizas, 1968; Papavizas and Lewis, 1971) and nematodes (Mojtahedi et al., 1993), but they may be herbicidal to desired plants (Brown and Morra, 1995). For example, processing waste from broccoli (Brassica oleracea L. Botrytis group) was successfully utilized to reduce levels of Verticillium dahliae Kleb. in field soil; no adverse effects on subsequent broccoli crops were reported (Subbarao and Hubbard, 1996). When used as a rotation crop, canola (formerly referred to as rape or rapeseed) moderately reduced symptoms of verticillium wilt of potato (Solanum tuberosum L.) (Davis et al., 1996). Canola incorporated into potting media reduced infection by Phytophthora cactorum (Lebert \& Cohn) J. Schröt. on tomato (Lycopersicon esculentum Mill.), but was phytotoxic to tomato at levels that reduced disease (Smith, 1994). Occurrence of stem lesions caused by $P$. cactorum was reduced by adding canola residue $\left(20 \mathrm{~g} \cdot \mathrm{L}^{-1}\right.$ per liter of potting mix), but plants were significantly stunted by the same amount in the absence of $P$. cactorum.
Germination of lettuce (Lactuca sativa L.) seed in enclosed bioassay chambers was greatly reduced by both volatile and water-soluble extracts of rapeseed meal (Brown and Morra, 1995).

The objective of the present study was to test the efficacy of using canola tissue to reduce damping-off of snap bean in the field, and to determine any phytotoxic effects of the canola itself on the snap beans. A preliminary report has been published (Smith, 1997).

\section{Materials and Methods}

Oven-dried leaves and petioles of canola cv. Humus were ground to pass a mesh screen with a $1-\mathrm{mm}^{2}$ opening (20 mesh) in a Wiley mill. Plants were collected just before seed set, when levels of glucosinolates are high (Mayton et al., 1996). Ground canola was stored dry in metal cans at $10^{\circ} \mathrm{C}$, and used as needed.

Each year before planting, germination tests were conducted on the snap bean seed lot to be used that year. In all cases, germination of the seed lots exceeded $99 \%$.

On 17 July 1995, 24 June 1996, and 16 June 1997, 'Bush Blue Lake' snap beans were planted in Watchaug fine sandy loam (coarseloamy, mixed, mesic, Aquic Dystrochrept) in Hamden, Conn. The area planted was the same every year. Initial $\mathrm{N}$ levels were 10 to 15 $\mathrm{mg} \cdot \mathrm{kg}^{-1}$, and no $\mathrm{N}$ fertilizer was added at any time. The area to be planted was cultivated with a rototiller, then raked smooth by hand; large stones and clods of earth were removed. Seeds were planted by hand, at a depth of $4 \mathrm{~cm}$ and with $4 \mathrm{~cm}$ between seeds. Cracked, broken, or discolored seeds were discarded. Between-row spacing was $46 \mathrm{~cm}$, and individual plot rows were $3.1 \mathrm{~m}$ long ( 80 seeds in $3.1 \mathrm{~m}$ ). All spacings were measured, not estimated. Treatment consisted of $200 \mathrm{~g}$ of dried, ground canola, applied directly to the seeds in a given 3.1-m furrow; seeds in half the rows were left untreated. Treatments were replicated 12 times in 1995 (24 plots total), and eight times in both 1996 and 1997 (16 plots total in both years). Plots were watered immediately after planting and thereafter as needed to supplement incident rainfall, and weeds were removed by hand. Damage by Mexican bean beetles (Epilachna varivestis Mulsant) was reduced in all years by removing larvae and adults by hand and by treating plots with Bacillus thuringiensis var. kurstaki de Barjac \& Lemille according to label recommendations. Stand counts were taken $14 \mathrm{~d}$ after planting and expressed as stand density (number of emerged plants per $3.1 \mathrm{~m}$ of row).

In all years, isolations were made from seedlings that did not emerge. Lesioned hypocotyls were plated onto water agar to detect pathogens, and subcultures were made on acidified potato dextrose agar and Komada's agar (1975) to identify fungi as to genus and species, when possible. Isolations for bacteria were not conducted.

Marketable pods were harvested beginning on 8 Sept 1995, 15 Aug 1996, and 7 Aug 1997 , and at 3- to 4-d intervals until yields declined to $<10 \%$ of the yield of the second 
Table 1. Effect of treatment with canola residue on stand establishment, number of trifoliates, nodulation, and yield of snap beans, 1995-97.

\begin{tabular}{|c|c|c|c|}
\hline \multirow[b]{2}{*}{ Criterion } & \multirow{2}{*}{$\begin{array}{c}\text { Year } \\
\text { (no. plots) }\end{array}$} & \multicolumn{2}{|c|}{ Canola } \\
\hline & & With & Without \\
\hline \multirow[t]{3}{*}{ Stand density (plants $/ 3.1 \mathrm{~m})^{\mathrm{z}}$} & $1995(24)$ & $36.6 \pm 1.06$ & $56.4 \pm 1.00^{* * *}$ \\
\hline & 1996 (16) & $14.7 \pm 2.20$ & $31.0 \pm 1.73^{* * *}$ \\
\hline & 1997 (16) & $27.3 \pm 3.08$ & $64.6 \pm 0.83^{* *}$ \\
\hline \multirow[t]{3}{*}{ No. of trifoliates ${ }^{z}$} & 1995 (24) & $17.3 \pm 2.78$ & $12.4 \pm 2.62^{\mathrm{Ns}}$ \\
\hline & 1996 (16) & $16.4 \pm 3.19$ & $15.4 \pm 3.93^{\mathrm{NS}}$ \\
\hline & 1997 (16) & $19.3 \pm 2.35$ & $9.7 \pm 1.31^{*}$ \\
\hline \multirow[t]{3}{*}{ Nodules per plant (no.) ${ }^{\mathrm{z}}$} & $1995(24)$ & $1.1 \pm 0.44$ & $0.3 \pm 0.12^{\mathrm{Ns}}$ \\
\hline & $1996(16)$ & $5.4 \pm 0.88$ & $1.0 \pm 0.71^{\mathrm{Ns}}$ \\
\hline & 1997 (16) & $9.4 \pm 3.13$ & $6.6 \pm 1.65^{*}$ \\
\hline \multirow[t]{3}{*}{ Total yield $(\mathrm{kg})^{\mathrm{y}}$} & 1995 (24) & 43.8 & $39.3^{\mathrm{Ns}}$ \\
\hline & 1996 (16) & 20.4 & $25.9^{\mathrm{Ns}}$ \\
\hline & 1997 (16) & 27.8 & $34.7^{\mathrm{Ns}}$ \\
\hline \multirow[t]{3}{*}{ Plants harvested (no.) ${ }^{\mathrm{x}}$} & 1995 (24) & 351 & $542^{* * *}$ \\
\hline & 1996 (16) & 130 & $250^{* *}$ \\
\hline & 1997 (16) & 165 & $381^{* *}$ \\
\hline \multirow[t]{3}{*}{ Yield/plant (g) } & 1995 (24) & 124.8 & $72.4^{\mathrm{NS}}$ \\
\hline & $1996(16)$ & 157.1 & $103.5^{\mathrm{Ns}}$ \\
\hline & 1997 (16) & 168.2 & $91.5^{\mathrm{Ns}}$ \\
\hline
\end{tabular}

${ }^{z}$ Mean \pm standard error of the mean.

y Total weight of marketable pods from the inner $1.8 \mathrm{~m}$ of all rows of that treatment. ${ }^{x}$ Total number of plants from which harvest data were taken.

Ns, *,**Nonsignificant or significant at $P \leq 0.05$ or $\leq 0.1$, respectively, by ANOVA. Comparisons are within years.
Table 2. Effect of canola residues on frequency of isolation of fungi from damped-off snap bean seedlings. In some instances, more than one fungus was isolated from a seedling.

\begin{tabular}{lcll}
\hline & & \multicolumn{2}{c}{ Canola } \\
\cline { 3 - 4 } Fungus genus & Year & With $^{\mathrm{z}}$ & Without $^{\mathrm{z}}$ \\
\hline Fusarium & 1995 & $31 / 132$ & $48 / 96$ \\
& 1996 & $46 / 195$ & $29 / 147$ \\
Pythium & 1997 & $49 / 159$ & $20 / 45$ \\
& 1995 & $9 / 132$ & $14 / 96$ \\
Phytophthora & 1996 & $12 / 195$ & $8 / 147$ \\
& 1997 & $13 / 159$ & $10 / 45$ \\
Rhizoctonia & 1995 & $1 / 132$ & $0 / 96$ \\
& 1996 & $0 / 195$ & $1 / 147$ \\
Other & 1995 & $1 / 159$ & $0 / 45$ \\
& 1996 & $13 / 132$ & $15 / 96$ \\
& 1997 & $12 / 195$ & $13 / 147$ \\
& 1995 & $15 / 139$ & $18 / 45$ \\
& 1996 & $24 / 195$ & $21 / 96$ \\
& 1997 & $20 / 159$ & $15 / 44$ \\
\hline
\end{tabular}

${ }^{2}$ Numerator is the number of damped-off seedlings from which the fungus was isolated; denominator is the number of damped-off seedlings from which isolations were attempted. picking. Pods were harvested multiple times to detect any differences in timing of maximum yield due to amendment with canola. Yield of marketable pods was recorded from the inner $1.8 \mathrm{~m}$ of each row, leaving $0.6 \mathrm{~m}$ at each end of each row as a buffer between adjoining rows.

After completion of the harvest, all plots were destructively sampled. Five plants were dug by hand from the middle of the harvested area of each row, and the number of trifoliates (used to estimate leaf area; Aylor 1988), total plant weight, and the number of nodules on the roots of each plant were recorded.

\section{Results}

In all 3 years, emergence of snap beans, expressed as stand density, was reduced by at least $64 \%$ by the addition of dried, ground canola in the furrow at the time of planting (Table 1). Daily minimum and maximum temperatures were similar in all three years, ranging from 8 to 20,13 to 27,15 to 30 , and 16 to $30{ }^{\circ} \mathrm{C}$, for the average minimum and maximum temperatures for May, June, July, and August, respectively, for 1995, 1996, and 1997. Detection of pathogens in seeds that did not emerge did not differ with treatment (Table 2).

Average leaf area of plants (estimated by the number of trifoliates) in rows with reduced stand (canola added) was increased in all years; differences were numerically but not statistically greater in 2 of the 3 years. Reductions in stand in all years resulted in larger plants and a corresponding increase in yield on a perplant basis. Total yield was higher in plots with reduced stand only in 1995; these plots were planted later in the summer and were subject to higher ambient temperatures in July and August. High temperatures may have contributed to an increased volatilization of the isothiocyanates. There was no effect of treatment on timing of maximum yield of marketable pods (data not presented). Nodulation was numerically greater in all 3 years in rows amended with canola.

\section{Conclusions}

Since the primary effect of adding canola residue to the furrow at planting was a suppression of bean seedling emergence, the isothiocyanates may be phytotoxic to germination. The cultivar of canola used in the present study was selected to be high in glucosinolates, the precursors to isothiocyanates. In plots with fewer plants, plants were larger (as reflected by a larger leaf area) than those in plots with more plants; decreased stand establishment in canola-treated plots did not affect yield, because of compensation by the remaining plants. The remaining plants in the canolatreated plots were larger and more productive than those in the plots not treated with canola.

Reduction in germination probably occurred because of addition of canola at planting. Since we did not explore the effects of addition of canola before planting, allowing the isothiocyanates to volatilize and escape from the soil, this topic remains for future research. Experiments are in progress to determine the level of volatilization, and subsequent reduction in efficacy, when canola is incorporated before planting.

Crucifers in general, high glucosinolate canola in particular, might be used to reduce or control damping-off in field-grown vegetables. The level at which pathogen populations are reduced without affecting seed germination needs to be determined, and will vary with the crop being grown. Such information will be useful in economically reducing losses in cool, wet, and/or disease-conducive soils.

\section{Literature Cited}

Auld, D.L., K.A. Mahler, D.A. Erickson, , and P.L. Raymer. 1992. Registration of 'Humus' rapeseed. Crop Sci. 32:1068.

Aylor, D.E. 1988. Development of bean rust epidemics in a field planted with alternate rows of a resistant and a susceptible snap bean cultivar. Phytopathology 78:1210-1215.

Brown, P.D. and M.J. Morra. 1995. Glucosinolatecontaining plant tissues as bioherbicides. J. Agr. Food Chem. 43:3070-3074.

Davis, J.R., O.C. Huisman, D.T. Westerman, S.L. Hafez, D.O. Everson, L.H. Sorensen, and A.T. Schneider. 1996. Effects of green manures on Verticillium wilt of potato. Phytopathology 86:444-453.

Gamliel, A. and J.J. Stapleton. 1993. Characterization of antifungal volatile compounds evolved from solarized soil amended with cabbage residues. Phytopathology 83:899-905.

Hall, R. (ed.). 1991. Compendium of bean diseases. APS Press, St. Paul, Minn.

Kirkegaard, J.A., P.T.A. Wong, and J.M. Desmarchelier. 1996. In vitro suppression of fungal root pathogens of cereals by Brassica tissues. Plant Pathol. 45:593-603.

Komada, H. 1975. Development of selective media for quantitative isolation of Fusarium oxysporum from natural soil. Rev. Plant Protection Res. 8:114-124.

Lewis, J.A. and G.C. Papavizas. 1971. Effect of sulfur-containing volatile compounds and vapors from cabbage decomposition on Aphanomyces euteiches. Phytopathology 61:208-214.

Mayton, H.S., C. Olivier, S.F. Vaughn, and R. Loria. 1996. Correlation of fungicidal activity of Brassica species with allyl isothiocyanate production in macerated leaf tissue. Phytopathology 86:267-271.

Mojtahedi, H., G.S. Santo, J.H. Wilson, and A.N. Hang. 1993. Managing Meloidogyne chitwoodi on potato with rapeseed green manure. Plant Dis. 77:42-46.

Muehlihen, A.M., R.E. Rand, and J.L. Parke. 1990. 
Evaluation of crucifer green manures for controlling Aphanomyces root rot of peas. Plant Dis. 74:651-654.

Papavizas, G.C. 1968. Survival of root-infecting fungi in soil. VI. Effect of amendments on bean root rot caused by Thielaviopsis basicola and on inoculum density of the causal organism. Phytopathology 58:421-428.

Papavizas, G.C. and J.A. Lewis. 1971. Effects of amendments and fungicides on Aphanomyces root rot of peas. Phytopathology 61:215-220.

Sang, J.P., I.R. Minchinton, P.K. Johnstone, and R.J.W. Trustcott. 1984. Glucosinolate profiles in the seed, root and leaf tissues of cabbage, mustard, rapeseed, and swede. Can. J. Plant Sci. 64:77-93.

Smith, V.L. 1994. Suppression of Phytophthora cactorum in vitro by volatiles from canola residues. Phytopathology 84:1138.

Smith, V.L. 1996. Enhancement of snap bean emer- gence by Gliocladium virens. HortScience 31:984-985.

Smith, V.L. 1997. Effect of canola amendment on emergence of snap bean. Phytopathology 87:S92.

Subbarao, K.V. and J.C. Hubbard. 1996. Interactive effects of broccoli residue and temperature on Verticillium dahliae microsclerotia in soil and on wilt in cauliflower. Phytopathology $86: 1303-$ 1310. 